\title{
In Vitro Chitosan Hydrogel Based Tetracycline Cytotoxicity Test on Fibroblast Viability
}

\author{
Andrew ${ }^{1}$, Irma Ervina ${ }^{2 *}$, Harry Agusnar ${ }^{3}$ \\ ${ }^{1}$ Periodontics Residency Program, Faculty of Dentistry, Universitas Sumatera Utara, Medan, \\ Indonesia \\ ${ }^{2}$ Department of Periodontics, Facullty of Dentistry, Universitas Sumatera Utara, Medan, \\ Indonesia \\ ${ }^{3}$ Department of Biology, Faculty of Mathematics and Natural Science, Universitas Sumatera \\ Utara, Medan, Indonesia \\ *Email: irma_ervina@rocketmail.com
}

\begin{abstract}
Tetracycline has been widely used as a periodontal support treatment since it has broad-spectrum bone tissue penetration and it can inhibit native collagen. Chitosan hydrogel-based tetracycline is known to have strong antibacterial effects, but the cytotoxic effects on fibroblast have yet to be studied. The objective of this study is to obtain the in vitro cytotoxicity effect of chitosan hydrogel-based tetracycline on fibroblasts. Chitosan hydrogel-based tetracycline $(0.5 \%, 0.7 \%$ and $1 \%$ ) and chitosan hydrogel without tetracycline is made by dissolving chitosan powder in citric acid. Tetracycline powder is then added to the solution. 3T3 fibroblast cells were cultured in a well microplate containing RPMI-1640 media inside an incubator. The viability assay is conducted using the MTT-assay method and repeated 5 times. The colour degradation is read with a microplate reader. The mean viability of fibroblasts applied with chitosan hydrogel-based tetracycline $(0.5 \%, 0.7 \%$ and $1 \%)$ and chitosan hydrogel is $86.5 \%, 85.36 \%, 80.99 \%$ and $90.85 \%$, respectively. The highest mean cell viability in the group of fibroblasts applied with chitosan hydrogel-based tetracycline is in the $0.5 \%$ group. This value is not significantly different than the value in the $0.7 \%$ group, but it is significantly different than the value in the $1 \%$ group. Chitosan hydrogel-based tetracycline shows a low cytotoxic effect on 3T3 fibroblast cells.
\end{abstract}

Keywords: tetracycline, chitosan, viability, cytotoxic

\section{Introduction}

Periodontal disease is considered one of the most common chronic dental diseases. This term encompasses gingivitis and periodontitis, both of which are caused by plaque-associated bacterial infections that accumulate in the periodontal pockets. Periodontal disease is managed by eliminating bacterial and inflammatory products through mechanical or chemical methods [1,2]. When used as a supportive treatment, local drug delivery provides better results, especially in patients with deep periodontal pockets.

Tetracycline is widely used because of its broad-spectrum effects, bone penetrating ability, MMPs and its ability to inhibit native collagen. According to Sachdeva, $0.7 \%$ is the concentration of tetracycline acceptable by tissues [3]. Recent developments of this method focus on employing controlled-release intra- 
pocket device systems that use fibres, films, gels, strips, vesicular systems, semisolids with micro- or nanoparticles, etc. Local drug delivery is more efficient since the drugs are directly applied to the bacteria. These yields fewer adverse effects and a lower chance of bacterial resistance [4].

Chitosan is a natural polysaccharide mucoadhesive formed through the Ndeacetylation of chitin, which is obtained from shrimp or crab shells. Chitosan and its derivatives have proven to be efficient drug transporters on mucous and transmucous because of their polymer cationic character. Their positively charged cationic nature promotes interaction with mucous epithelium. This increases the distance between cells and allows macromolecule transportation through the epithelial barrier $[4,5]$.

The bactericidal and bacteriostatic effects of chitosan have been widely studied since the 1980s. Chitosan's bacteriostatic effects are due to its interactions with ions on cell walls. Nutrition supplies for microbes are suppressed because m-RNA and protein synthesis is inhibited, as chitosan penetrates the microbe's nucleus and creates an external barrier. The molecule weight and the degree of deacetylation plays an important role and is inversely proportional to the effectiveness of microorganism suppression [6]. This effect has been confirmed by Susanto et al. (2017) in his study about the effectiveness of chitosan hydrogel-based tetracycline on some periodontal pathogens [7]. The aim of this work is to obtain the in vitro cytotoxicity effect of chitosan hydrogel-based tetracycline on fibroblasts.

\section{Material and methods}

The chitosan, provided by the Chemistry Department at the Universitas Sumatera Utara, was processed from shrimp shells. Tetracycline hydrochloride was purchased from PT. Mutifa. 3T3 Fibroblast cell lines were cultured by the Parasitology Laboratory at the University of Gadjah Mada. All other chemicals used in this study were of analytical grade.

The chitosan hydrogel $(4 \% \mathrm{w} / \mathrm{w})$ was prepared following the method formulated by Popa et al.(2013) by continuously mixing (by hand) 2 grams of chitosan with an adequate amount of citric acid (1\%)4 Tetracycline hydrochloride $(0.5 \%$, $0.7 \%$ and $1 \%$ ) were then dissolved in the $4 \%$ chitosan hydrogel. The result was a homogeneous hydrogel. The hydrogel was then mechanically cross-linked by cooling down to $4^{\circ} \mathrm{C}$ prior to use. Based on the study conducted by Susanto et al. (2017), the amounts of chitosan, tetracycline hydrochloride and citric acid were modified to improve the gel viscosity for local usage (Table 1) [7].

To obtain 1 x 104 cell/well density, 3T3 fibroblast cell lines were cultured in microplates containing 1640 media from Rosewell Park Memorial Institute and incubated for 24 hours. After the media were washed with PBS and refreshed, 25 $\mu l$ of each experimental hydrogel was then added to the microplates. This was followed by a $5 \% \mathrm{CO} 2$ incubation process at $37^{\circ} \mathrm{C}$ for 24 hours. 
Table 1. Composition of the chitosan hydrogel based tetracycline $0.5 \%, 0.7 \%$ and $1 \%$ and chitosan hydrogel without tetracycline.

\begin{tabular}{|l|c|c|c|}
\hline \multirow{2}{*}{\multicolumn{1}{|c|}{ Hydrogel group }} & \multicolumn{3}{|c|}{ Material } \\
\cline { 2 - 4 } & Chitosan & Tetracycline & Citric acid $1 \%$ \\
\hline Tetracycline $0.5 \%$ & $2 \mathrm{gr}$ & $0,25 \mathrm{gr}$ & $50 \mathrm{ml}$ \\
\hline Tetracycline $0,7 \%$ & $2 \mathrm{gr}$ & $0,35 \mathrm{gr}$ & $50 \mathrm{ml}$ \\
\hline Tetracycline1\% & $2 \mathrm{gr}$ & $0,5 \mathrm{gr}$ & $50 \mathrm{ml}$ \\
\hline Chitosan hydrogel & $2 \mathrm{gr}$ & - & $50 \mathrm{ml}$ \\
\hline
\end{tabular}

After 24 hours, the solution in the wells was flicked off and $50 \mu 1$ of MTT dye was added to each well. The microplates were then packed and left at room temperature for an entire night. A total of 130 wells were used; the control and blank groups comprised 5 wells and the experimental hydrogel groups comprised 25 wells. The absorbency level was measured using a microplate reader at a wavelength of $595 \mathrm{~nm}$. The percentage of cell viability was calculated using the following formula:

$\%$ Cell viability $=\frac{(\text { Absrobance value of test compound }- \text { Absorbance value of blank })}{(\text { Absorbance value of control }- \text { Absorbance value of blank })} \times 100$

The percentage of cell inhibition was calculated by subtracting the percentage of cell viability from 100 . The Saphiro-Wilk normality test was conducted on the viability results, followed by the ANOVA test. The results were considered statistically significant when the $\mathrm{p}$ value was $<0.05$.

\section{Result}

The absorbency level results in Table 2 were obtained from the microplate reader. Each of the mean values were then used to calculate the viability of the $3 \mathrm{~T} 3$ fibroblast cells using the aforementioned formula (Table 3).

Table 3 shows that the highest mean of cell viability is with chitosan hydrogel. However, the highest mean of cell viability in the chitosan hydrogel-based tetracycline group is a concentration of $0.5 \%$.

The viability percentage of each experimental group was measured by the Saphiro-Wilk normality test, resulting in normal distributions with significance levels greater than 0.05 (Table 4). The ANOVA test was then conducted to determine if there were any significant differences in each group's viability percentages (Table 5). 
Table 2. Absorbance result of each hydrogel groups on 3 T3 fibroblast cells.

\begin{tabular}{|l|c|c|}
\hline Groups & Mean, \pm SD & Min-Max \\
\hline Cell Control & $0.625, \pm 0.024$ & $0.591-0.635$ \\
\hline Blank Control & $0.08, \pm 0.05$ & $0.079-0.087$ \\
\hline Chitosan & $0.577, \pm 0.004$ & $0.575-0.586$ \\
\hline hydrogel & $0.575, \pm 0.005$ & $0.567-0.582$ \\
\hline & $0.575, \pm 0.006$ & $0.567-0.582$ \\
\hline & $0.573, \pm 0.003$ & $0.568-0.575$ \\
\hline & $0.576, \pm 0.004$ & $0.572-0.584$ \\
\hline Tetracycline & $0.553, \pm 0.009$ & $0.522-0.561$ \\
\hline $0.50 \%$ & $0.55, \pm 0.005$ & $0.544-0.557$ \\
\hline & $0.553, \pm 0.003$ & $0.552-0.561$ \\
\hline & $0.551, \pm 0.003$ & $0.552-0.559$ \\
\hline & $0.551, \pm 0.004$ & $0.549-0.558$ \\
\hline Tetracycline & $0.546, \pm 0.017$ & $0.517-0.546$ \\
\hline $0.70 \%$ & $0.543, \pm 0.003$ & $0.552-0.547$ \\
\hline & $0.547, \pm 0.002$ & $0.544-0.549$ \\
\hline & $0.545, \pm 0.006$ & $0.539-0.554$ \\
\hline & $0.545, \pm 0.005$ & $0.539-0.551$ \\
\hline Tetracycline & $0.521, \pm 0.007$ & $0.509-0.528$ \\
\hline $1.00 \%$ & $0.52, \pm 0.004$ & $0.514-0.523$ \\
\hline & $0.523, \pm 0.004$ & $0.524-0.528$ \\
\hline & $0.521, \pm 0.006$ & $0.512-0.524$ \\
\hline & $0.522, \pm 0.005$ & $0.513-0.526$ \\
\hline & & \\
\hline & &
\end{tabular}

Table 3. Viability and inhibition percentage of Chitosan Hydrogel based Tetracycline

\begin{tabular}{|l|c|c|c|}
\hline & $\begin{array}{c}\% \text { Viability } \\
\text { Mean, } \pm \text { SD }\end{array}$ & $\begin{array}{c}\text { \% Inhibition } \\
\text { Mean }, \pm \text { SD }\end{array}$ & Min-Max \\
\hline Chitosan hydrogel & $90.85 \pm 0.55$ & $1.15 \pm 0.55$ & $90-91$ \\
\hline Tetracycline $0.5 \%$ & $86.53 \pm 0.55$ & $13.47 \pm 0.55$ & $86-87$ \\
\hline Tetracycline 0.7\% & $85.36 \pm 0.55$ & $14.64 \pm 0.55$ & $85-86$ \\
\hline Tetracycline 1\% & $80.99 \pm 0.55$ & $19.01 \pm 0.55$ & $78-81$ \\
\hline
\end{tabular}


Table 4. Normality test result

\begin{tabular}{|l|r|}
\hline$\%$ Viability & Significance \\
\hline Chitosan hydrogel & 0.635 \\
\hline Tetracycline $0.5 \%$ & 0.814 \\
\hline Tetracycline $0.7 \%$ & 0.777 \\
\hline Tetracycline $1 \%$ & 0.201 \\
\hline
\end{tabular}

Saphiro-Wilk Normality test $\mathrm{p}>0.05$

Table 5. Comparison of chitosan hydrogel based tetracycline cytotoxic effect on fibro-

\begin{tabular}{|l|c|c|c|c|}
\hline & betracycline 0.5\% & Tetracycline 0.7\% & Tetracycline 1\% & Chitosan hydrogel \\
\hline Tetracycline 0.5\% & - & 0.007 & $0.000^{*}$ & $0.000^{*}$ \\
\hline Tetracycline 0.7\% & 0.007 & - & $0.000^{*}$ & $0.000^{*}$ \\
\hline Tetracycline 1\% & $0.000^{*}$ & $0.000^{*}$ & - & $0.000^{*}$ \\
\hline Chitosan hydrogel & $0.000^{*}$ & $0.000^{*}$ & $0.000^{*}$ & - \\
\hline
\end{tabular}

ANOVA test

*Significant $\mathrm{p}<0.05$

In the chitosan hydrogel-based tetracycline group, the highest cell viability mean was found in the $0.5 \%$ tetracycline group. There was no significant difference in the $0.7 \%$ tetracycline group, but there was a significant difference in the $1 \%$ tetracycline group.

\section{Discussion}

This study concluded that all concentrations of hydrogel showed no cytotoxicity effect on 3T3 fibroblast cells according to ISO 1099-395. This states that viability percentages above $80 \%$ are considered non-cytotoxic. ISO 1099-395 further states that viability percentages between $80 \%$ to $60 \%$ are considered weak, viability percentages between $60 \%$ to $40 \%$ are considered moderate and viability percentages below $40 \%$ are considered strong [8]. The highest viability percentage $(90.85 \%)$ was found in the $4 \%$ chitosan hydrogel group, while the lowest viability percentage $(80.99 \%)$ was found in the $1 \%$ tetracycline group. Grobler et al. and Zhang et al. both concluded that the cytotoxic effect of chitosan will increase along with the concentration level $[9,10]$. Arancibia et al. reported that any chitosan concentration higher than $5 \mathrm{mg} / \mathrm{ml}$ may cause cytotoxicity on human gingiva fibroblasts [11].

Chitosan has been widely used in the pharmaceutical field due to its low toxicity. Chitosan is biodegradable, mucoadhesive and non-toxic It also has high bio- 
compatibility and low solubility in neutral environments [12]. Its biodegradability could prevent accumulation and allow for self-sustaining release.

Due to its advantages, chitosan has been widely used as drug carrier or a wound healing agent. Hydrogel is known as a three-dimensional hydrophilic polymer that can absorb and retain levels of water, or any biological fluid, up to onethousand times heavier than its dry weight. Hydrogel may have a chemical stability that degrades and dissolves over time. This 'aging' process of hydrogel could be inhibited by the cross-linking method $[13,14]$.

Hydrogel has good biocompatibility because of its low surface tension, which allows it to be used as an absorbent solvent for cell adhesions. Hydrogel also has a high-water content, and it can stimulate several types of tissue. Additionally, its soft character allows for low irritation and mechanical friction on living tissues $[15,16,17]$. Having all these qualities, hydrogel is suited for use as a macromolecular vehicle in medical applications [18].

Tetracycline is one of the most popular antibiotics for treating anaerobic bacterial infections [19]. Tetracycline can be used to support conventional therapies that may be ineffective on certain patients. Combination treatments are known to be more effective than standalone treatments [20]. Although it is believed to be safe, a recent study shows that tetracycline inhibits certain proteins and cell proliferation by binding to $30 \mathrm{~S}$ ribosomal sub-units. It can also alter the integrity of mammalian cell membranes, resulting in macromolecular dysfunction, cellular lysis and cellular mortality $[21,22,23]$. An inhibitive effect of tetracycline on protein translation, which is managed by mitochondrial DNA on mammalian cells, has been reported. This inhibition will trigger the imbalance of mitochondrial protein, which will lead to interference with growth, oxygen consumption and fertility $[24,25]$.

Various viability percentages achieved in this study might result from chitosan's controlled drug-release character. Based on the study done by Zhang et al., it was found that chitosan has a sustained-release ability that lasts for 5 days [26]. Zhang et al. also reported the characteristics of low toxicity towards 3T3 fibroblast cells and high biocompatibility when chitosan was combined with tetracycline.

Chitosan hydrogel-based tetracycline $(0.5 \%, 0.7 \%$ and $1 \%)$ shows high viability and non-cytotoxic effects on 3T3 fibroblast cells. Chitosan hydrogel 4\% shows good biocompatibility and no toxicity on $3 \mathrm{~T} 3$ fibroblast cells.

\section{Conclusions}

Chitosan hydrogel-based tetracycline shows a low cytotoxic effect on 3T3 fibroblast cells.

\section{References}

1. Carranza FA, Takei H. The Treatment Plan. In Carranza's Clinical Periodontology. 12th edition, St. Louis, Saunders-Elsevier; 2012:125-6.

2. Meharwade VV, Gayathri GV, Mehta DS. Effects of scaling and root planing with or without a local drug delivery system on the gingival crevicular fluid leptin level in chronic periodontitis patients: a clinico-biochemical study. J Periodont Implant Sci. 2014;44(3):118-25. 
3. Sachdeva S, Agarwal V. Evaluation of commercially available biodegradable tetracycline fiber therapy in chronic periodontitis. J Indian Soc Periodontol. 2011;15(2):130.

4. Popa LĂ, Ghica MV, Dinu-Pirvu CR. Periodontal chitosan-gels designed for improved local intra-pocket drug delivery. Farmacia. 2013;61(2):240-50.

5. Rodrigues S, Dionísio M, López CR, Grenha A. Biocompatibility of chitosan carriers with application in drug delivery. J Func Biomat. 2012;3(3):615-41.

6. Goy RC et.al. A Review of the Antimicrobial Activity of Chitosan. Polimeros: Ciencia e Tecnologia. 2009;19(3):241-7.

7. Chandra Susanto IE, Agusnar H. In vitro evaluation of antimicrobial effectiveness chitosan based tetracycline gel on some pathogenic periodontal bacteria. Int J Appl Dent Sci. 2017;3(2):71-6

8. López-García J, Lehocký M, Humpolíček P, Sáha P. HaCaT keratinocytes response on antimicrobial atelocollagen substrates: extent of cytotoxicity, cell viability and proliferation. J Func Biomat. 2014;5(2):43-57.

9. Zhang W, Ren G, Xu H, Zhang J, Liu H, Mu S, Cai X, Wu T. Genipin cross-linked chitosan hydrogel for the controlled release of tetracycline with controlled release property, lower cytotoxicity, and long-term bioactivity. J Polymer Res. 2016;23(8):156.

10. Grobler SR. Cytotoxic Effect of Chitosan-H, Resveratrol, $\beta$-Carotene and Propolisand their Chitosan Hydro-gels On Balb/C Mouse 3T3 Fibroblast Cells. Int J Dentistry Oral Sci. 2014 Dec 11;1(2):10-4.

11. Yi H, Wu LQ, Bentley WE, Ghodssi R, Rubloff GW, Culver JN, Payne GF. Biofabrication with chitosan. Biomacromolecules. 2005 Nov 14;6(6):2881-94.

12. Arancibia R, Maturana C, Silva D, Tobar N, Tapia C, Salazar JC, Martínez J, Smith PC. Effects of chitosan particles in periodontal pathogens and gingival fibroblasts. J Dent Res. 2013;92(8):740-5.

13. Erizal E, Redja IW. Sintesis Hidrogel Superabsorben Polietilen Oksida-Alginat dengan Teknik Radiasi Gamma dan Karakterisasinya. Jurnal Ilmu Kefarmasian Indonesia. 2010 Apr 30;8(1):11-7.

14. Bajpai AK, Giri A. Swelling dynamics of a macromolecular hydrophilic network and evaluation of its potential for controlled release of agrochemicals. Reactive Funct Polymers. 2002 Dec 1;53(2-3):125-41.

15. Schacht E, Gevaert A, Molly K, Verstraete W, Adriaensens P, Carleer R, Gelan J. Polymers for colon specific drug delivery. J Controlled release. 1996 May 1;39(2-3):32738.

16. Abdel-Mohsen AM, Aly AS, Hrdina R, Montaser AS, Hebeish A. Eco-synthesis of PVA/chitosan hydrogels for biomedical application. J Polymer Environ. 2011 Dec 1;19(4):1005-12

17. Rohindra DR, Nand AV, Khurma JR. Swelling properties of chitosan hydrogels. South Pacific J Nat Appl Sci. 2004;22(1):32-5.

18. Wu QX, Lin DQ, Yao SJ. Design of chitosan and its water soluble derivatives-based drug carriers with polyelectrolyte complexes. Marine drugs. 2014;12(12):6236-53.

19. Dumitrescu AL. The Topical Use of Antibiotics in Perioedontal Pockets. In Antibiotics and antiseptics in periodontal therapy. SpringerLink (Online service); 2011:171.

20. Maria Gerrad. Treatment of Periodontal Disease. Ineedce,2009:1-8.

21. Adnyasari N.L.P.S.M. Pemberian Tetrasiklin HCL secara Gel secara Topikal Konsentrasi $0,4 \%$ lebih Mempercepat Proliferasi Kolagen dibandingkan dengan Konsentrasi0,2\% dan 0,1\% pada Gingiva Tikus yang Meradang. Tesis Program Magister Program Studi Ilmu Biomedik Program Pasca Sarjana Universitas Udayana Denpasar, 2012.

22. Brodersen DE, Clemons Jr WM, Carter AP, Morgan-Warren RJ, Wimberly BT, Ramakrishnan $\mathrm{V}$. The structural basis for the action of the antibiotics tetracycline, pactamy- 
cin, and hygromycin B on the 30S ribosomal subunit. Cell. 2000 Dec 22;103(7):114354.

23. McKee EE, Ferguson M, Bentley AT, Marks TA. Inhibition of mammalian mitochondrial protein synthesis by oxazolidinones. Antimicrobial agents and chemotherapy. 2006 Jun 1;50(6):2042-9.

24. Moullan N, Mouchiroud L, Wang X, Ryu D, Williams EG, Mottis A, Jovaisaite V, Frochaux MV, Quiros PM, Deplancke B, Houtkooper RH. Tetracyclines disturb mitochondrial function across eukaryotic models: a call for caution in biomedical research. Cell reports. 2015 Mar 17;10(10):1681-91.

25. Chatzispyrou IA, Held NM, Mouchiroud L, Auwerx J, Houtkooper RH. Tetracycline antibiotics impair mitochondrial function and its experimental use confounds research. Cancer Res. 2015 Nov 1;75(21):4446-9.

26. Agusnar H, Noviary H. Preparasi dan Karakterisasi Kitosan dari Cangkang Belangkas yang Diikat silang dengan Modifikasi Genipin. Prosiding Seminar Nasional Sains dan Teknologi Nuklir PTNBR-BATAN, Bandung, 2013. 